\title{
Varieties of Militarism: Towards a Typology
}

The final published version of this manuscript is available in Security Dialogue vol 49, no 12, pp. 96-108: https://doi.org/10.1177/0967010617730948

DOI: $10.1177 / 0967010617730948$

Accepted for Publication: 6/7/2017

Bryan Mabee

School of Politics and International Relations

Queen Mary, University of London

b.mabee@qmul.ac.uk

Srdjan Vucetic

Graduate School of Public and International Affairs

University of Ottawa

Srdjan.Vucetic@uottawa.ca

\begin{abstract}
:
Militarism - a mercurial, endlessly contested concept - is experiencing a renaissance of sorts in many corners of the social science community. In critical security studies, the concept's purview has become increasingly limited by an abiding theoretical and analytical focus on various practices of securitisation. We argue that there is a need to clarify the logic and stakes of different forms of militarism. Critical security scholars have provided valuable insights into the conditions of 'exceptionalist militarism.' However, if we accept that militarism and the production of security are co-constitutive, then we have every reason to consider different manifestations of militarism, their historical trajectories and their inter-relationships. To that end, we draw on the work of historical sociologists and articulate three more ideal types of militarism: nation-state militarism, civil society militarism, and neoliberal militarism. We suggest this typology can more adequately capture key transformations of militarism in the modern period as well as inform further research on the militarism-security nexus.
\end{abstract}

\section{Introduction}

Scholarship on militarism is going through a lean period in the study of security. Critical security studies (CSS) is no exception: the 'classic' concerns of the literature on militarism as political violence — its causes, effects, phasing, evolution — are of little or no interest in a field increasingly devoted to 'new wars,' new technologies of war, 'liberal war' and notions of risk (Stavrianakis and Selby, 2012a). If it were not for a steady stream of scholarly production on the subject coming mainly from feminist theorists in select outlets, one would be tempted to conclude the study of militarism is now the province of sociologists and geographers. One exception is the work on securitisation-the critical scrutiny of the ways in which 
constitutional or 'normal' politics are transformed, via speech acts, into 'exceptions'. Conceived in the late 1980s and early 1990s as part of an agenda that sought to orient research away from the undue reduction of security to military affairs, securitisation theory eventually came to accept the centrality of military power to the emergence and development of security issues (Doty, 1998-9; Neumann, 1998). Today, it can be said that securitisation theory has inspired a whole body of research on what can be called 'exceptionalist militarism'.

In this article we attempt to situate this unsung contribution of securitisation studies in the established research tradition on militarism in historical sociology. Drawing on the contributions of Michael Mann and Martin Shaw, and specifically the idea that militarisms can be distinguished in terms of the 'typical social forces' and 'prevailing social relations' as their 'core determinants,' we situate 'exceptionalist militarism' in a typology that also includes 'nation-state militarism,' 'civil society militarism' and 'neoliberal militarism'. An engagement with the broader concept and practices of militarism would advantage CSS by drawing attention to the social and historical context in which security is produced. If we accept that militarism and the production of security are co-constitutive, then we have every reason to consider different manifestations of militarism, their historical trajectories and their inter-relationships. We begin by situating the core literature on militarism in the in the context of recent debates from CSS. Drawing on the contributions of Mann and Shaw, we then develop a typology of militarisms that yields our four ideal types. After reflecting on the ways in which this typology could be useful to CSS, we conclude with some thoughts on the future study of militarism and its relation to security.

\section{Wherefore Militarism?}

While the study of security retains at its core the study of military power, much of what this entails is taken for granted and subjected to a real neglect due to established norms concerning the scope and uses of military power. This applies broadly to both 'realist' and 'liberal' investigations of military power, as typified in the U.S. context by normative 
invocations around the use of force or reoccurring policy debates concerning the 'correct' levels of military spending (e.g., Foreign Affairs, 2016, c.f. Mabee and Vucetic, 2017). For over two decades, CSS scholars have shown the limits of such perspectives: established categories of analysis often obfuscate as much as they illuminate, to say nothing of failing to match new realities. Looking at the substantive contents of a leading CSS textbook (Peoples and Vaughan-Williams, 2014), we see that the expansion of the study of security now fruitfully includes: environmental security, health, homeland security and the 'war against terror', human security and development, migration and border security, and technology and warfare in the information age. What we do not see, however, is a sustained attention to the concept of militarism. Similarly, the two leading CSS journals - International Political Sociology and Security Dialogue - have published very few pieces where the main focus is on militarism (or militarisation). ${ }^{1}$ Although overlaps exist between militarism on the one hand and areas such as ecology and policing on the other, this literature has not been fully engaged with the military as an institution, or in terms of the ideology of militarism (Stavrianakis and Selby, 2012a: 10). Overall, the theoretical and analytical focus of CSS has tended to be on the ways in which 'violence' is brought into areas beyond that of direct interest to the military rather than on the continued relevance of the military as key institution of power. This indeed is the necessary context for understanding the recent creation of separate journal that deals directly with issues to do with the military - Critical Military Studies (there is also an emergent field of Critical War Studies with overlapping themes, that relies on a similar critique of CSS: see Barkawi, 2011). We think the reasons behind this systematic side-lining of militarism in CSS lie in the genealogy of the field, and specifically the attempt of some of its progenitors to move the study of security away from the study of military affairs (Buzan \& Wæver, 1997: 242). This has been accomplished: CSS contributions to the knowledge of other 'sectors' of security, of sovereign authority, of politics and the political are all

\footnotetext{
${ }^{1}$ For International Political Sociology, from 2007-2017, there were only four articles with some variation on 'militarism' or 'militarization' in the title and five in the abstract (adding up to six overall). In Security Dialogue, between 2002-2017, there were no articles with 'militarism' in the title, one with 'militarization'; and two with 'militarism' in the abstract; a search of 'militarism', 'militarized' and 'militarization' as a 'topic' yielded 10 results. Details available upon request.
} 
significant and influential (Wæver, 2011). However, it is now time to bring military affairs back in, and specifically militarism.

It is important to recognize the concept's essential ambiguities (Berghahn, 1984). Semantically, the acquisition of the potential for force or the relative weight and importance of the state's military in relation to its society (see the Global Militarization Index by the Bonn International Center for Conversion, for example) is sometimes conflated with the disposition to use force ('militarism'), which in turn confuses debates over hypothesised cause-effect relationships between the two processes. More fundamentally, conceptual ambiguities are sociological and philosophical. In the classic work by John Gillis (1989), for example, the militarism-militarisation distinction is linked to social stratification and modernisation, with the analysis apprehending the difference between a class approach to militarism ('militarism' thus describing the domination of society by an atavistic social class) and one that saw militarism as a form of economic life ('militarisation' thus depicting forms of industrialisation with the military at their core). Begin with an alternative social theory, as Catherine Lutz (2002) does, and militarisation becomes the discursive production of symbolic and representational militarised realities. This is also why different scholars interpret the 'same' militarised realities so differently: the nature of the military/police distinction (Weiss, 2011; Neocleous, 2014) or the rise of the 'virtual'/“virtuous war' (Ignatieff, 2000; Der Derian, 2001), for example.

In historical sociology, and especially the neo-Weberian historical sociology of the 1970s and 1980s, the question of conceptualisation revolves around two basic questions: how fundamental is militarism to political and social life? (i.e. is it a property of all states and societies?); and how does the historicity of the concept of militarism frame our explanations of it? (Shaw 2012). Mann, in the context of his broader studies of social power, has dealt with these core issues through a series of macro-sociological and typological frameworks that looked at the phasing and co-evolution of militarism on the one hand and different types of states, forms of popular sovereignty, and racial ideologies on the other (Mann, 1988, 1996; c.f. 1993). His main argument is that understanding modern society requires sustained attention to militarism, which he defines as 'a set of attitudes and social practises which 
regards war and the preparation for war as a normal and desirable social activity' (1987: 166; also see Eastwood, this issue).

Mann's expansive conception of militarism can be productive for CSS because it links both disposition and social purpose. Preparing for war (including the institutionalisation of militaries, and the networks of logistics and production required to support them) will exist wherever military power is seen as useful, both internally (e.g. for pacifying populations, economic growth) and externally (e.g. for achieving expansive goals). In this way, militarism research orients itself to the general questions of social and political order rather than the more specific questions such as those around military capitalisation and civilian control. This is in line with the vision of CSS for two reasons. First, it alerts us to the agents operating outside, or parallel to, state structures, which, as Mann argues, are responsible for some of the most ferocious manifestations of militarism in history. Second, it highlights military power as that which circulates, and is embodied, beyond the state rather than something that is or is not controlled by assorted state actors, as in liberal and institutionalist theories (e.g. Caverley 2014).

In more recent work, Mann has moved to define militarism in terms of ideological power, specifically that related to patriarchy and masculinity (for example: 2012, 134; c.f. Mann, 1986a). This offers yet another useful connection with CSS, this time via the rich feminist and gender literature on militarism (see, inter alia, Dyvik and Greenwood, 2016; Sjoberg and Via, 2010; Wibben, this issue). While focusing more on the micro level (and generally more culturally orientated in its conceptualisation and operationalisation of militarism), this work provides an important foundation for macro work. Furthermore, to the extent that sociologists are interested in explaining properties and actions of individual agents, their focus is undeniably on collective phenomena that are not reducible to the actions, beliefs or desires of any single member of a given society. However, a good sociological account always looks at the relations, processes and mechanisms by which social (or sociocultural) structures constrain individual action and interaction as well as for the relations, processes and mechanisms by which individual action and interaction produces social structures (see Alexander and Gieson, 1987; and Layder, 1994). This is why we think our typology could 
inform both macro-historical accounts and the accounts of the relational structures in which individuals' actions occur. In other words, we need to move back and forth between the micro and macro to get a fuller picture of militarism, charting out connections between microcontexts, the ways in which guiding ideas of militarism travel, and how they are reinterpreted and applied in other contexts. We also take this approach to be essential to the study of global militarism that moves away from 'methodological nationalism' and towards appreciation of 'global connections' (Stavrianakis and Selby, 2012a: 15).

Where Mann outlines a broader macro-understanding of militarism, Shaw provides the basis for our typology, seeing in militarism two main determinants: 'the typical social forces mobilised in military power' and 'the social relations of military power (2012: 4-5). The 'typical social forces' refer to economic, political, cultural resources mobilised by social constituencies - that is, by complex configurations of different actors, institutions, and practices situated at once in a particular society and the broader social and historical context. As Shaw describes it, 'we are talking about the role of socialised warfare in a militarised economy and society' (Shaw, 1988: 24). As such, war and society need to be seen as inseparable, with militarism as a kind of ligature between the two. Shaw's second main determinant of militarism, 'the social relations of military power,' refers to 'the always potentially antagonistic relation between armed actors (combatants) and civilians (noncombatants)' (2012: 5). Unless it is perfectly pacifist and non-violent or, conversely, it is organised such that warfare and preparation for warfare are an end in itself ('most states have militaries, but in Prussia the military has a state,' as one popular caricature holds), a society is likely to struggle to establish a 'workable' relationship with organised violence. Interest in the social relations of military power is shared by scholars of civil-military relations, whether those working on the venerable problems of professionalism and control mentioned earlier or on the newer developments such as the civilianisation of military organisations, the marginalisation of the military functions of the state (especially in terms of how civil-military relations are a form of power; see e.g. Basham, 2016), or how civil-military relations intersect with gender, race, class, sexuality and post-coloniality (Baker, et al, 2016). 
To the extent that CSS deals with militarism, the field's focus is on analysing ideas, discourses, policies, institutions and processes within specific sites or nationally bounded networks. We believe that the study of security within CSS can benefit from seeing militarism as a global and transnational phenomenon, and specifically from the historical sociological perspectives à la Mann and Shaw. To that end, we develop a typology of the 'macrodynamics' of militarism.

\section{Towards a Typology}

Weberian ideal types-abstractions distilled from concrete phenomena-serve to categorise, compare and contrast complex social systems, and in some cases map out the historical trajectory of social transformation. The typology developed below is not intended to be transhistorical. It is meant to convey present categories as a means to bring some order to a messier reality, in a given time period. In doing so, the typology brings what Mann (1986b: 4) refers to as 'proximate methodology', while acknowledging a 'skeptical empiricism' (Mann, 1986b: 4) towards the boundaries that typologies create. The typology recognises the historical contingencies and context inherent in the concept of militarism, though revolving around a core focus on the purposeful use of organised violence. Our starting point is a recognition that 'social forces mobilised in military power' are engendered by general technological revolutions, reigning rationalities and organisational logics, the mode of capitalist development and other factors. They also intersect with religion, gender, race, ethnicity, nationhood and other axes of identification that construct, reproduce and restructure social reality and human experience. Building on previous typological studies of militarism, we suggest that a core element of said social forces of socio-economic liberalisation (Joana and Mérand, 2014). This is of course a convenient simplification. The 'social relations of military power,' Shaw's second core determinant of militarism, is seen in the myriad forms of conflict and stratification of militaries (and other violent organisations) as organisational actors within and across societies. This can be best seen in the forms of stratification between 'soldiers' and 'civilians', as in the notions of 'separation' and 'fusion' (or 'blurring'), terms derived the classic debates on civil-military relations in the liberal-institutional tradition. 
Separation typically means that armed forces are 'professional'-that is, apolitical and subordinate to civilian authority (e.g., Huntington, 1957, 8-18), but we expand this out to look at ways in which militaries are functionally separate from the civilian population, and potentially autonomous actors with regard to political power. Fusion refers to the collapse of the conventional or formal civil/military distinction (also see Grassiani, this issue).

Much like the binaries we use to think about security in CSS (inside/outside, public/private, military/policy, war/peace, security/insecurity, militarization/de-militarization, war/law enforcement), the civil/military binary is problematic. For one, formally dividing the non-uniformed civilians in government from the uniformed military has a tendency to mask rather than elucidate the ways in which militarism influences society. As much of the literature on civil-military relations is about order, not surprisingly we could take much of this further in terms of the idea of 'civil' rule being disordered and 'military' rule being ordered. Our approach conceives the military as an institution (or even organisation, as Mann does), contrasting ideal-typically with the political-organisational power of the state. This allows for a distinction in purpose and process, while also revealing different entwinings of both formal and informal networks of power implicated in the categories 'civil' and 'military.' The constitutional guarantee of civilian autonomy, for example, cannot prevent military values, beliefs, organisational culture, language, and technology from shaping different areas of the civilian life (e.g., Enloe, 2000; c.f. Woodward, 2016: esp. 53). 'Separation' therefore implies an ideal type where the institutions are functionally separate, and 'fusion' where the political/state cannot be separated from the military/organised violence.

Different configurations and interactions of, respectively, the 'social forces' and 'prevailing social relations' yield different militarisms. CSS, on its part, has dealt with what can be called 'exceptionalist' militarism. However, militarism can be parsed into three more ideal types that are of relevance to the field. We label these, provisionally, 'nation-statist,' 'civil society', 'neoliberal'.

Exceptionalist militarism relates to the concept of the exception, as articulated in the thought of the one-time Nazi jurist Carl Schmitt (2005) [1934]) and more recently by theorists 
of the political Left, such as, above all, Giorgio Agamben (2005). Much of this thought revolves the political and legal constitution of sovereignty through the suspension of regular legislative and judicial rules and procedures, via unified civil society support, for the purposes of dealing with enemies and security threats (Huysmans, 2006). This is the core of Schmitt's claim that the 'sovereign is he who decides on the exception' (2005: 5). This framework is relevant for the conceptualisation of militarism: if any political order can suspended through state-of-emergency decisions undertaken in defence of the state against the enemy, then it follows the separation between the armed forces and the state is always contingent and indeterminate. Similarly, if the ultimate test of sovereignty is war, then militarism may be necessary for the political to exist (Schmitt, 2007 [1932]: 34-35).

The re-articulation of state sovereignty through the state of exception has received much attention by CSS scholars interested in power grabs, loss of individual freedom, and exclusionary and dehumanising tendencies in the context of the zones of free movement (e.g., Bigo, 2000) and the global modalities of 'liberal warfare' (Dillon and Reid, 2009), including various exceptional militarised practices associated with the U.S.-led 'war on terror'detention camps, extraordinary rendition and aerial targeted killings (Grayson, 2016). Certainly, alternative Schmittian readings of militarism are possible-its role in the constitution of the nomos, Schmitt's term for the distribution of spheres of influence in international politics, that is, spatially distributed external authority (Odysseos and Petito, eds. 2007, esp. Part IV), for example. Yet there are good reasons why CSS has focused on liberal democratic exceptionalism. If, for instance, it can be shown that contemporary U.S. constitutional and practical checks and balances cannot impede the sovereign's decision to mobilise military power in response to urgent, extraordinary and existential threats, then exceptional militarism is likely to be a side-product of securitisation processes everywhere. It is the same for the social forces implicated in the rise of the market society: if thoroughly capitalist advanced liberal democracies states engage in exceptionalist militaristic practices, then all polities can, too. What is more, following in part the interpretations of Schmitt by Claudia Aradau (2007) and Renato Cristi (1998), it may well be that capitalist development is 
co-constitutive with exceptionalism and the juridical, political and military transformations it effectuates.

Nation-statist militarism is the default ('normal') setting for militarism in international and global life. Following Mann, this manifestation of militarism is characterised by some form of civilian control over the armed forces and a state-led economic and social mobilisation of 'destructive' forces. An ideal-typical example is modern Prussia: in claiming legitimate authority, its leaders prioritised territorial defence; planned, built and consumed from its own arsenals; and engaged in military recruitment practices that reflected and reinforced the prevailing social structures of the nation (whether professionalised or conscripted) - hence an effort to turn male Junker landowners into the officers of the army, rather than male serfs, shopkeepers, Polish nobles or some other group. ${ }^{2}$

Nation-statist militarism is sometimes dubbed 'Westphalian militarism' (Joana and Mérand, 2014) and even 'Keynesian militarism'-a version of the idea that governments can and should pursue counter-cyclical policies such as, in this case, the use of military spending to boost employment and economic activity when the economy is sagging. Nation-statist militarism also subsumes Mann's (1996) categories of 'authoritarian militarism' and 'liberal militarism' as these are fundamentally statist; indeed, Mann used them to demonstrate historical shifts in militarism involving the absolutist European polities and their twentieth century authoritarian descendants (e.g. Germany, Russia) on the one hand and the polities deriving from constitutional regimes (e.g. Britain, France) on the other. ${ }^{3}$ Nation-statist further subsumes the militarisms of the post-1945 nuclear age, which include, in Mann's terminology, sub-types like 'deterrence-science militarism' ('techno-scientific militarism') and 'spectator sport militarism.' All of these labels capture essential aspects of contemporary militarism involving the state and nation. While often seen as a militarism of the past, nation-

\footnotetext{
${ }^{2}$ The Prussian social militarisation thesis has been much criticised, revised and re-vised since receiving theoretical attention in the middle years of the twentieth century by Otto Büsch and others. For more on this and nearby examples, see Frevert (2004).

${ }^{3}$ Mann's typologies of militarism can be seen as Eurocentric (Shaw, 1991). For a more global perspective in the same tradition, see Abernethy (2002).
} 
statist it is one that consistently reasserts itself, and needs to be accounted for (Mabee and Vucetic, 2017).

The third type of militarism still derives from a pronounced statism, but thrives on deliberately blurred lines between soldiers and civilians. The classic manifestation is what Mann calls civil society militarism - the use of organised military violence in pursuit of social goals that is 'state-supported, but not state-led' (1996: 235). This conceptualisation is especially helpful in thinking about Europe's liberal regimes from the perspectives of their colonial empires in the Americas, Africa, Asia, and Australasia (Mann, 1996: 235, 237). Indeed, in assessing the sordid history of civil society militarism, Mann deliberately draws parallels with nation-statist militarism, including the 'militarised socialism' of the Soviet Union and the Nazi German 'nation-racist' militarism: 'So viewed, in the nineteenth and twentieth centuries, only a handful of European countries - the Nordics (minus Finland), Switzerland, and Luxembourg — can be meaningfully described as liberal pacifist' (Ibid.: 1996: 233).

Mann discusses civil society militarism as a sub-set of liberal militarism. What we wish to emphasize are organizational similarities between violence inherent to modern European (and Japanese) colonial imperialism on the one hand and para-military and para-legal forms of substate violence characteristic of the rise of fascism in the interwar period on the other. The rise of paramilitary organizations in Weimar Germany is an example (Berghahn, 2006). More importantly, although not as pervasive and powerful as in the era of colonial empires, military power continues to be mobilised by civilian actors even today. Many criminal, terrorist and insurgent groups belong to the 'state-supported, but not state-led' rubric, but their activities constitute only one dimension of civil society militarism. The Mexico-United States border control ecology has over the past decade included a number of the so-called vigilante groups, such as the now-defunct Minuteman Civil Defence Corps or the American Border Patrol, whose leaders are now keen to share their expertise with the Trump administration. There, militarism is configured in the deployment of military veterans, military hardware and tactics (drones and small planes engaged in intelligence, surveillance, and reconnaissance 
operations), and military culture (camouflage outfits, command structure) to 'monitor the border' and, in some cases, interdict and detain border-crossing immigrants as well. ${ }^{4}$

The ongoing 'refugee crisis' (a.k.a. the human crisis or crisis of being a refugee) in Europe has witnessed similar developments, at varying scales, everywhere from Spanish North Africa to Bulgaria to Finland. Other contemporary examples include armed civilian groups that participate in activities described as anti-crime (e.g., extra-judicial killings occurring as part of Philippine leader Rodrigo Duterte's 'war on drugs' today or by Brazil's justiceiros in the 1990s), counterterrorism (e.g., against Boko Haram in the Sahel), counterinsurgency operations (e.g., eastern Ukraine) and cultural policing (e.g., gau rakshaks, or cow protectors, in India). Indeed, what is remarkable here is not the decline of armed civilian groups replacing or shadowing state-run border control, police and military forces, but their stickiness in modern life (Pratten and Sen, 2007). How these groups define threats to individual or collective security, what they do to check or remove those threats, how they manage to co-exist with state institutions, and what ramifications all of this has for different security agendas are questions yet to be systematically examined in CSS.

Neoliberal militarism refers to the configuration of social forces and social relations in which military mobilisation is achieved at once through the framework of socio-economic liberalisation and through the formal division between (professional) soldiers and civilians. Its conceptual predecessor, liberal militarism, was originally developed to identify and explain the uniqueness of the British experience. According to David Edgerton (1991), Britain has long been characterised by an elite-mass consensus on the need to shift the costs of war onto professional soldiers and foreigners and a corollary preference for force structures geared to conventional high technology war-fighting ('capital-intensive') as opposed to that rigged for labour-intensive tasks such as long-term occupation. This idea was further developed by Mann and Shaw, who used it to identify, respectively, the evolution of militaristic activities of

\footnotetext{
${ }^{4}$ For the latest updates on the latter, see http://americanborderpatrol.com/ (Last accessed on 21 January 2017). For a rare study of this phenomenon in CSS, albeit from the perspective of what we call exceptionalist militarism, see Doty (2007).
} 
the West European liberal democracies in the nineteenth and twentieth centuries (Mann, 1988 ; 1996) and in the twenty first century (Shaw, 1991, 2005, 2012).

In their recent typology of liberal militarism, which focuses on contemporary Western Europe, Jean Joana and Frédéric Mérand (2014) make a convincing case that the post-1970s and 1980s economic liberalisation has considerably transformed the enactment of militaristic activities (also see Basham, this issue). The expansion of the ideas, institutions and practices of neoliberal capitalism certainly transformed the social forces mobilised in military power, first in the Euro-Atlantic area, and then globally. However, the 'market society' conditions the mobilisation of military power from the way it causes new fractures in society, as Karl Polanyi argued in The Great Transformation, and the development of specific modes of governance that emerge from liberalism and neoliberalism, as examined by Michel Foucault in The Birth of Biopolitics. The relevant developments are thus not simply the marketisation of defence procurement and of personnel management and the decline of the military draft, but also include the rise of private military actors such as neo-mercenary and security companies (staffed by military veterans using high-tech military gear-see Abrahamsen and Williams 2011 and Grassiani, this issue), the privatisation and spread of military logistics (and its overlaps with corporate logistics - see Cowen, 2014), the proliferation of new military technologies (as in 'smart' border control—see Bigo, 2014), and the growing openness and competition in the international arms market (e.g. Halper, 2014). The mechanics of late capitalism go hand-in-hand with (neo)liberal imagination of freedom and fluidity.

The most brittle boundary among our ideal types is between nation-statist militarism and neoliberal militarism. Socio-economic liberalisation does not necessarily lead to the weakening of the nation state. Although some neoliberal developments are clearly reflected in, and reinforced by, an increasing geographic dispersion of production and consumption of military goods and services as well as in the growth of truly multinational military development and production, they do not impact all states and societies, and certainly not in uniform ways. The military draft, for example, remains in place in much of the world outside Europe and while no European state has abolished it by constitutional fiat, some, like Sweden, 
are now re-introducing it. All that said, the neoliberal imagination has and is likely to continue to impact the beliefs, values and practices of many military institutions.

\section{What Next?}

Typologies help theorists map out different aspects of the phenomena they study and identify areas of relative under-theorisation. The purpose of this typology has been to show that CSS lacks, but needs to have, a better appreciation of militarism and its different forms. The chief reason is the importance of context. If historical sociologists are right, the production of security cannot be separated from the sources of social power and therefore from the attitudes and practices involving warfare. The typical social forces and the prevailing social relations that give rise to diverse forms of militarism in different historical, social and political contexts are also likely to give rise to different meanings of security (c.f. Abrahamsen, this issue). As many critics have pointed out in the case of securitisation research, the nation-statist, liberal, and Western priors that dominate this scholarship do not have universal purchase. ${ }^{5}$

Are the borders created by such a typology too neat in terms of caging what cannot be caged? Only if the alternative is methodological uncertainty. The point of the typology is not to deem anything that falls in between categories as marginal or irrelevant, but mainly to demonstrate diversity within the broad category of militarism. We indeed think of it as a useful guide to moving away from militarism as a mainly statist concept, by introducing a range of other forms of militarism and a means to looking at them globally. The typology is also meant as a means to furthering research in CSS, namely by illustrating the ways in which different forms of modern militarism fit within a broader field of critical security. Focusing only on one form of militarism, as in securitisation research, risks a conceptually impoverished portrayal of the social and political world and quite possibly a depoliticised depiction of violence as well (see Eastwood, this issue).

\footnotetext{
${ }^{5}$ This especially applies to the first generation securitisation studies. For discussions, see, inter alia, Williams (1998), Doty (1998-9), Wilkinson (2007), Barkawi (2011), and the contributions to the 2011 Security Dialogue special issue on 'The Politics of Securitization Theory', especially Wæver (2011).
} 
Another distinct benefit in thinking militarism typologically is that it helps us trace its main historical lineages. A substantial historical engagement is necessary for better understanding the contemporary dynamics of military power, not only seeing the changes taking place today, but their specific historical trajectories. We would argue that if there is historical movement in our typology, it is clearly at present pushed by socio-economic liberalisation, rather than a shift in the boundaries between soldiers and civilians. What to make of this movement is another matter. We might want to clearly link this shift up to developments in global capitalism—surely crucial—but linking the trajectories of militarism too straightforwardly to political economic tendencies would betray some core insights of the historical sociological literature that we draw on: seeing militarism and military power as contingently related to other forms of power. This is why it is so crucial not lose sight of the other modes of militarism, and also see how readily they fit into the prevailing norms or ideologies concerning the 'usefulness' of military power. Attention to such developments can go a long way in helping CSS scholars meet the aforementioned demand for better contextual awareness.

Typologies can additionally help identify the conditions under which different aspects of the phenomena relate each other. A case in point is the relationship between civil society militarism and the other three types. One of the core goals of CSS has always been to recast the study of security away from dominant - usually translating as state- and military-centricdiscourses, institutions, and practices. Yet, if civil society militarism is characterised by state support, then the theoretical and analytical emphasis should be on the means through which that state support materialises - and these can entail normal, exceptional, and neoliberal components, to various degrees and in various combinations. The bigger picture of these arguments is the situating of militarism in either the interstices of state power, or, in terms of the reconfiguration of political power. Going back to Hardt and Negri (2005), militarism as a dimension of power is increasingly biopolitical, meaning engendering the management of populations in the Foucauldian sense, and global in reach ('Empire'). To more fully understand these reconfigurations, CSS would therefore have to not only think more broadly 
about exceptionalist militarism, but also about how exceptionalist militarism is co-determined by other forms of militarism.

\section{Conclusions}

The stakes of understanding the diverse modalities of militarism are as high as ever. As should be clear from the typology above, we see present day CSS as mainly influenced by 'exceptionalist militarism'. In some ways this is not entirely surprising due to Western scholars' abiding interest in the US-led 'war on terror.' However, despite any insights that this quite extensive literature has brought, the inclusion of other modalities of militarism is crucial for both seeing more diversity in practice in contemporary global politics, but also for understanding the historical trajectories and local variations of militarism.

In terms of the future study of militarism, it is important to continue to diversify how we look at militarism. We think typological analysis is helpful, but what is even more helpful is a devotion to the historical sociological examination of militarism, especially looking at it through a global lens rather than a statist one. This entails sustained attention to the interaction between the social forces and social relations of militarism in the context of multiple political fields and histories and the ways they function not in isolation, but in coordination and co-constitution with larger dynamics of power in the world. CSS has an opportunity to make a major advance in contemporary scholarship by examining the constitution of this 'global militarism.' 


\section{References}

Abrahamsen R \& M Williams (2011) Security Beyond the State. Cambridge: Cambridge University Press.

Abernethy DB (2002) The Dynamics of Global Dominance: European Overseas Empires, 1415-1980. New Haven, Conn.: Yale University Press.

Agamben G (2005) State of Exception. Chicago: University of Chicago Press.

Alexander JC and Giesen B (1987) From Reduction to Linkage: The Long View of the Micro-Macro Debate. In J.C. Alexander et al. (eds.) The Micro-Macro Link. Berkeley: University of California Press.

Aradau C (2007) Law Transformed: Guantanamo and the 'Other' Exception. Third World Quarterly 28(3) 489-502.

Baker C, Basham V, Bulmer S, Gray H and Hyde A (2016) Encounters with the Military. International Feminist Journal of Politics 18(1): 140-154.

Barkawi T (2011) From War to Security: Security Studies, the Wider Agenda and the Fate of the Study of War. Millennium: Journal of International Studies 39(3): 1-16.

Basham VM (2016) Raising an Army: The Geopolitics of Militarizing the Lives of WorkingClass Boys in an Age of Austerity. International Political Sociology 10(3): 258-274.

Berghahn VR (1984) Militarism: The History of an International Debate. Cambridge: Cambridge University Press.

Berghahn VR (2006) Europe in the Era of Two World Wars: From Militarism and Genocide to Civil Society, 1900-1950. Princeton: Princeton University Press.

Bigo D (2014) The (in)securitization practices of the three universes of EU border control: Military/Navy - border guards/police - database analysts. Security Dialogue 45(3): 209225.

Bigo D (2000) When two become one: Internal and external securitisations in Europe. In Kelstrup M and Williams MC (eds) International Relations Theory and the Politics of European Integration. London: Routledge, 171-203.

Buzan B and Wæver O (1997) Slippery? Contradictory? Sociologically Untenable? The Copenhagen School Replies. Review of International Studies 23(1): 241-250.

Caverley J (2014) Democratic Militarism: Voting, Wealth, and War. Cambridge: Cambridge University Press.

Cowen D (2014) The Deadly Life of Logistics: Mapping Violence in Global Trade. Minneapolis: University of Minnesota Press.

Cristi R (1998) Carl Schmitt and Authoritarian Liberalism: Strong State, Free Economy. Cardiff, University of Wales Press.

Der Derian J (2001) Virtuous War: Mapping the Military-Industrial-Media-Entertainment Network. Boulder: Westview Press.

Dillon M and Reid J (2009) The Liberal Way of War: Killing to Make Life Live. London and New York: Routledge.

Doty R (1998/9) Immigration and the Politics of Security. Security Studies 8(2-3): 71-93.

Doty R (2007) States of Exception on the Mexico-U. S. Border: Security, 'Decisions,' and Civilian Border Patrols. International Political Sociology 1(2): 113-137.

Dyvik SL and Greenwood L (2016) Special Issue Introduction: 'Embodying Militarism: Exploring the Spaces and Bodies In-Between'. Critical Military Studies 2(1): 1-6. 
Edgerton, D (1991) Liberal Militarism and the British State, New Left Review 185:138-169.

Enloe C (2000) Maneuvers: The International Politics of Militarizing Women's Lives. Berkeley: University of California Press.

Foreign Affairs (2016) Tomorrow's Military: How Much is Enough? (Forum) 95(5): 2-45.

Frevert U (2004) A Nation in Barracks: Modern Germany, Military Conscription and Civil Society. Oxford: Berg Publishers,

Gillis JR (ed) (1989) The Militarization of the Western World. New Brunswick, NJ: Rutgers University Press.

Grayson K (2016) Cultural Politics of Targeted Killing: On Drones, Counter-Insurgency, and Violence. London: Routledge.

Halper J (2014). War Against the People: Israel, the Palestinians and Global Pacification. London: Pluto Press.

Hardt M and Negri A (2005) Multitude. London: Hamish Hamilton.

Huntington SP (1957) Soldier and the State: The Theory and Politics of Civil-Military Relations. Cambridge: Belknap Press of Harvard University Press.

Huysmans J (2006) The Politics of Insecurity: Fear, Migration and Asylum in the $E U$. London: Routledge.

Ignatieff M (2000) Virtual War: Kosovo and Beyond. New York: Holt.

Joana J and F Mérand (2014) The varieties of liberal militarism: A typology. French Politics 12(2): 177-191.

Layder D (1994) Understanding Social Analysis. London: Sage.

Lutz C (2002) Making war at home in the United States: Militarization and the current crisis. American Anthropologist 104(3): 723-735.

Mabee, B and Vucetic, S (2017), Militarism in the Age of Trump, Parts I and II. The Disorder of Things. Retrieved from https://thedisorderofthings.com/2017/03/17/militarism-in-theage-of-trump-part-i/

Mann M (1986a) A Crisis in Stratification Theory? Persons, Households/Families/Lineages, Genders, Classes and Nations. In Compton $\mathrm{R}$ and Mann $\mathrm{M}$ (eds) Gender and Stratification. Cambridge: Polity.

Mann M (1986b) The Sources of Social Power, Vol. I. Cambridge: Cambridge University Press.

Mann M (1987) The roots and contradictions of militarism. New Left Review 162: 35-50.

Mann M (1988) States, War and Capitalism. Oxford: Blackwell.

Mann M (1993) The Sources of Social Power, Vol. II. Cambridge: Cambridge University Press.

Mann M (1996) Authoritarian and Liberal Militarism: A Contribution from Comparative and Historical Sociology. In Smith S, Booth K and Zalewski M (eds) International Theory: Positivism and Beyond. Cambridge: Cambridge University Press.

Mann M (2012) The Sources of Social Power, Volume III: Global Empires and Revolution, 1890-1945. Cambridge: Cambridge University Press.

Neocleous M (2014) War power, police power. Edinburgh: Edinburgh University Press.

Neumann I (1998) Identity and the Outbreak of War: Or Why the Copenhagen School of Security Studies should include the idea of 'Violisation' in its Framework of Analysis. International Journal of Peace Studies 3(1): 7-22. 
Odysseos L and Petito F (eds) The International Political Thought of Carl Schmitt: Terror, Liberal War and the Crisis of Global Order. London: Routledge.

Peoples C and Vaughan-Williams N (2014) Critical Security Studies: An Introduction. $2^{\text {nd }}$ ed. Abingdon: Routledge.

Pratten D and Sen A (eds) (2007) Global Vigilantes: Perspectives on Justice and Violence, New York: Columbia University Press.

Schmitt C (2007) [1932] The Concept of the Political. Trans. G Schwab. Chicago: University of Chicago Press.

Schmitt C (2005) [1934] Political Theology: Four chapters on the Concept of Sovereignty. Chicago: University of Chicago Press.

Shaw M (1988) Dialectics of War. London: Pluto.

Shaw M (1991) Post-Military Society: Militarism, Demilitarization and War at the End of the Twentieth Century. Cambridge: Polity.

Shaw M (2005) The New Western War of War. Cambridge: Polity.

Shaw M (2012) Twenty-First Century Militarism: A Historical-Sociological Framework. In Stavrianakis A and Selby J (eds) Militarism and International Relations: Political Economy, Security, Theory. London: Routledge.

Sjoberg L and Via S (eds) (2010) Gender, War and Militarism: Feminist Perspectives. Santa Barbara: Praeger.

Stavrianakis A and Selby J (2012) Militarism and International Relations in the Twenty-first Century. In Stavrianakis A and Selby J (eds) Militarism and International Relations: Political Economy, Security, Theory. London: Routledge.

Wæver O (2011) Politics, security, theory. Security Dialogue 42(4-5): 465-480.

Weiss T (2011) The blurring border between the police and the military: a debate without foundations. Cooperation and Conflict 46(3): 396-405.

Wilkinson C (2007) The Copenhagen School on tour in Kyrgystan: Is securitization theory useable outside Europe? Security Dialogue 38(1): 5-25.

Williams M (1998) 'Modernity, Identity and Security: A Comment on the 'Copenhagen Controversy'. Review of International Studies 24(3): 435-439.

Woodward R (2016) Military landscapes: Agendas and approaches for future research. Progress in Human Geography 38(1): 40-61. 